\title{
LXXXVI. On hydrate of magnesia
}

\section{G.O. Rees M.D. F.G.S.}

To cite this article: G.O. Rees M.D. F.G.S. (1837) LXXXVI. On hydrate of magnesia, Philosophical Magazine Series 3, 10:63, 454-455, DOI: 10.1080/14786443708649197

To link to this article: http://dx.doi.org/10.1080/14786443708649197

册 Published online: 01 Jun 2009.

Submit your article to this journal 준

LII Article views: 2

Q View related articles $₫$ 
and the high lights sallow; and where the delicately transparent tints shed their deepening beauty opacity gratually supervenes. But those which are fixed in enamel will carry on unchanged to a period indefinitely remote the most delicate as well as the richest of the tints originally imparted by the pencil of the artist; and as he left the portrait of the sage, the poet, the warrior, and the beauty, so will they remain, when even the marble which portrayed their forms or told their history may have crumbled into dust.

35, Northaimpton-street, Clerkenwell, March 1837.

LXXXVI. On Hydrate of Magnesia. By G. O. Rees, M.D., F.G.S., \&c.

To Richard Phillips, Esq., F.R.S., \&.c. Dear Sir,

GHOULD you think the following worthy of notice, pray favour me by inserting it in the Philosophical Magazine.

Your sincerely obliged, 59, Guilford Street, Russell Square,

G. O. REES. May 16, 1837

It has been supposed by some chemists that magnesia is capable of uniting with water in several proportions, though no analysis seems to have been made of the artificial hydrate of that earth. The native hydrate of magnesia from America, analysed by Dr. Bruce, yielded in 100 parts,

$$
\begin{aligned}
& \text { Magnesia............ } 70 \\
& \text { Water ............. } 30-100 .
\end{aligned}
$$

A specimen of the same mineral from Unst, analysed by Dr. Fyffe, yielded in 100 parts,

$$
\begin{aligned}
& \text { Magnesia............ 69.75 } \\
& \text { Water............ } 30.25-100 .
\end{aligned}
$$

The results of two analyses made by myself of the artificial hydrate agree very nearly with the proportions obtained by Dr. Fyffe from the native specimen. Thus in a first experiment 100 parts yielded,

$$
\begin{array}{ll}
\text { Magnesia............. } & 69 \cdot 63 \\
\text { Water............. } & 30 \cdot 37-100 .
\end{array}
$$

A second experiment gave,

$$
\begin{aligned}
& \text { Magnesia............ } 69 \cdot 4.1 \\
& \text { Water ............. } 30.59-100 .
\end{aligned}
$$

These specimens were prepared by digesting recently calcined magnesia in cold distilled water and then drying the 
mixture over a water-bath. The first was digested in a wellclosed vessel during fourteen days: but no greater combining proportion of water was observed than in the second specimen, which was only digested for twenty-four hours.-I have procured a similar result by merely moistening the earth, and immediately drying it over the water-bath. The combination is inmediate, and, as has been shown, admits of no increase in the proportion of water by a prolonged digestion. If boiling water be used in forming the hydrate, no difference is observed in its constitution. It may be remarked how nearly the first analysis approaches to the proportions of atorn 10 atom, for assuming 20.7 as the atomic weight of magnesia, we have,

$$
\begin{aligned}
& \text { Magnesia........... } 20 \cdot 7 \\
& \text { Water ............. } 9 \cdot 02
\end{aligned}
$$

It seems certain from these experiments, that magnesia is capable of combining with water in one proportion only.

'The precipitate obtained by the addition of ammonia to a. neutral solution of sulphate of magnesia approaches also very nearly in constitution to a protohydrate of the earth. I found 100 parts of the precypitate (well dried over a water-batb) to yield

Magnesia...........66.7 66.7

Water.............. 33.3- 100 .

LXXXVII. Replies by Mr. E. M. Clarke, the Rev. Professor Callan, and Dr. Ritchie to certain Papers on Subjects of Electricity and Magneto-electricity inserted in the preceding and present Volumes of the Philosophical Magasine.

THE following is the substance of communications which we have received from the gentlemen above named. We have omitted nothing which could tend to elucidate the subjects under discussion: indeed the reply of the Rev. Professor Callan to Dr. Ritchie, and that of the latter to the Rev. J. W. MacGauley, are inserted almost entire.

$R_{e}$ ply of Mr. E. M. Clarke to Mr. J. Saxton. (See vol.ix. p. 360). "I proceed to reply to Mr. Saxton's remarks one by one. In the first place I have not laid claim to the electromagretic machine (as he calls $\mathrm{i}_{\text {i }}$ ) as my invention, but $\mathrm{l}$ have certainly termed:a magnetic electrical machine E. M. Clarke's, owing to a material difference having been made in its construction, the advantages arising from which $I$ shall now proceed to point out. First, it will readily be armitted that vibration tends to injure the magnets. In Mr. Saxton's machine very great vibration is unavoidable, in as much as all the ma- 